\title{
ALIRAN PERDAGANGAN LADA INDONESIA DI PASAR INTERNASIONAL
}

\author{
Eka Miftakhul Jannah ${ }^{1 *}$, Rita Nurmalina ${ }^{2}$, Ratna Winandi Asmarantaka ${ }^{2}$ \\ ${ }^{1}$ Program Studi Agribisnis, Sekolah Pascasarjana Institut Pertanian Bogor, Jl. Kamper Wing 4 Level 5 \\ Kampus IPB Darmaga, Bogor 16680 Indonesia \\ ${ }^{2}$ Departemen Agribisnis, Fakultas Ekonomi dan Manajemen Institut Pernanian Bogor, Jl. Kamper \\ Wing 4 Level 5 Kampus IPB Darmaga, Bogor 16680 Indonesia \\ *E-mail: eka_eg@yahoo.com
}

\section{RINGKASAN}

Indonesia merupakan salah satu negara produsen dan eksportir lada terbesar di dunia. Namun pertumbuhan volume ekspor lada Indonesia memiliki pertumbuhan lebih rendah dari pertumbuhan produksinya. Rendahnya ekspor lada Indonesia disebabkan oleh berbagai faktor yang mempengaruhi perdagangan lada Indonesia di pasar internasional. Adapun tujuan dari penelitian ini untuk menganalisis faktor-faktor yang mempengaruhi perdagangan lada Indonesia di pasar internasional dan menjelaskan potensi perdagangan lada Indonesia di negara tujuan. Metode analisis yang digunakan adalah analisis data panel dengan gravity model dan analisis potensi perdagangan. Hasil penelitian menunjukkan bahwa aliran perdagangan ekspor lada Indonesia secara signifikan sangat dipengaruhi oleh nilai GDP riil per kapita Indonesia, GDP riil per kapita negara tujuan ekspor, jarak ekonomi Indonesia dengan negara tujuan ekspor, nilai tukar rupiah terhadap negara tujuan ekspor, dan nilai RCA Indonesia. Namun demikian tarif impor negara tujuan ekspor tidak memiliki pengaruh signifikan. Indonesia memiliki potensi untuk terus meningkatkan perdagangan lada terhadap negara China, Malaysia, Taiwan, Belanda, Perancis, dan Jerman. Hal ini disebabkan perdagangan lada Indonesia dengan mitra dagang masih mengalami under trade. Sementara China merupakan negara yang memiliki potensi perdagangan paling tinggi.

Kata Kunci: ekspor impor, lada, perdagangan internasional, potensi perdagangan.

\section{PERNYATAAN KUNCI}

Aliran perdagangan ekspor lada Indonesia secara signifikan sangat dipengaruhi oleh nilai GDP riil per kapita Indonesia, GDP riil per kapita negara tujuan ekspor, jarak ekonomi Indonesia dengan negara tujuan ekspor, nilai tukar rupiah terhadap negara tujuan ekspor, dan nilai RCA Indonesia, namun penerapan tarif impor tidak berpengaruh secara signifikan. Sementara variabel GDP riil per kapita negara tujuan ekspor dan RCA Indonesia yang memiliki tanda hubungan yang sesuai dengan hipotesis. 
Indonesia memiliki potensi untuk terus meningkatkan perdagangan lada terhadap negara China, Malaysia, Taiwan, Belanda, Perancis, dan Jerman. Hal ini disebabkan perdagangan lada Indonesia dengan mitra dagang masih mengalami under trade. Namun demikian, China merupakan negara yang memiliki potensi perdagangan paling tinggi.

\section{REKOMENDASI KEBIJAKAN}

Indonesia juga perlu melakukan pendekatan yang intensif untuk menciptakan kerjasama bilateral dengan China karena potensi perdagangan China merupakan yang tertinggi, sedangkan ekspor lada Indonesia ke negara tersebut masih relatif kecil. Hal ini penting dilakukan karena pasar China relatif masih terbuka sementara permintaan impor China terhadap lada dunia cenderung tidak stabil.

I. PENDAHULUAN
Lada adalah salah satu produk rempah-rempah dari sub sektor perkebunan. Perdagangan lada memiliki kontribusi yang cukup penting dalam upaya pemerintah meningkatkan pendapatan nasional. Perdagangan lada dan beberapa komoditas perkebunan lain seperti kelapa sawit, kopi, teh, dan kakao di pasar internasional telah mampu meningkatkan PDB nasional. Total PDB yang dihasilkan dari komoditas lada pada tahun 2013 sebesar 342 juta US\$ atau 1,5\% dari total PDB sub sektor perkebunan (Ditjenbun, 2014). Selain itu, budidaya lada sudah mampu menyerap tenaga kerja di wilayah perdesaan sebesar 262.574 rumah tangga (Fajaria, 2016). Perkebunan lada merupakan usaha padat karya yang mampu menyerap tenaga kerja cukup banyak. Usaha lada yang intensif dan efisien memerlukan $1 \mathrm{KK}$ untuk luasan 0,5 ha (Suwarto, 2013). Untuk itu, usaha perkebunan lada dapat memberikan manfaaat secara ekonomi bagi

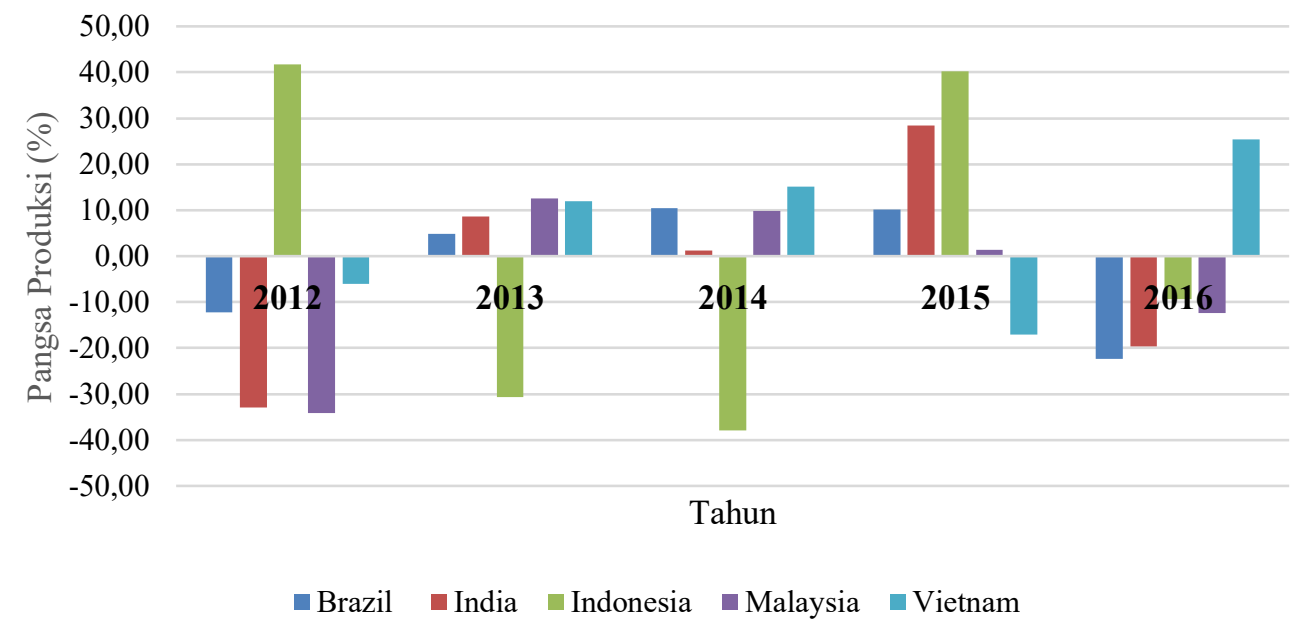

Sumber: IPC, 2017 (diolah)

Gambar 1. Perkembangan pangsa produksi lada di negara produsen lada dunia tahun 20022016 
Indonesia sehingga memiliki potensi untuk terus dikembangkan.

Perkebunan lada Indonesia tersebar di beberapa propinsi sehingga produksi lada nasional cukup besar. Berdasarkan data dari Internasional Trade Center (ITC, 2017), pada tahun 2016 produksi lada nasional mencapai 53.100 ton. Produksi nasional yang tinggi tersebut menempatkan Indonesia sebagai produsen lada terbesar kedua di dunia setelah Vietnam. Hal ini dapat terlihat pada Gambar 1 yang menunjukkan kontribusi produksi lada Indonesia terhadap produksi lada dunia yang merupakan terbesar kedua setelah Vietnam. Pada tahun 2012 dan tahun 2015 pangsa produksi lada Indonesia menunjukkan peningkatan dengan jumlah tertinggi sebesar $41.72 \%$ dan $40.19 \%$. Namun pada tahun 2016 pangsa produksi lada Indonesia mengalami penurunan. Pangsa produksi lada terbesar dunia dikuasai oleh Vietnam, di mana hampir setengah dari produksi lada dunia dikuasai oleh Vietnam. Namun demikian, Indonesia masih memiliki posisi penting sebagai salah satu produsen sekaligus pengekspor lada terbesar dunia.

Menurut data ITC pada tahun 2016 terdapat lebih dari 40 negara tujuan ekspor lada Indonesia di pasar internasional, beberapa negara diantaranya menjadi tujuan ekspor utama Indonesia, yaitu Vietnam, India, Amerika Serikat, Jerman, Singapura, Belanda, Taiwan, China, Perancis dan Malaysia. Negara tersebut telah menjadi mitra dagang utama lada Indonesia dengan volume ekspor rata-rata terbesar selama 5 tahun terakhir. Secara tradisional, Amerika Serikat merupakan negara tujuan utama ekspor lada Indonesia dengan rata-rata volume ekspor lada sebesar 13.399 ton. Namun demikian, sejak tahun 2015 Vietnam merupakan negara tujuan ekspor terbesar Indonesia dengan total volume ekspor 22.645 ton. Pada kurun tahun 2012 sampai tahun 2016, volume ekspor lada

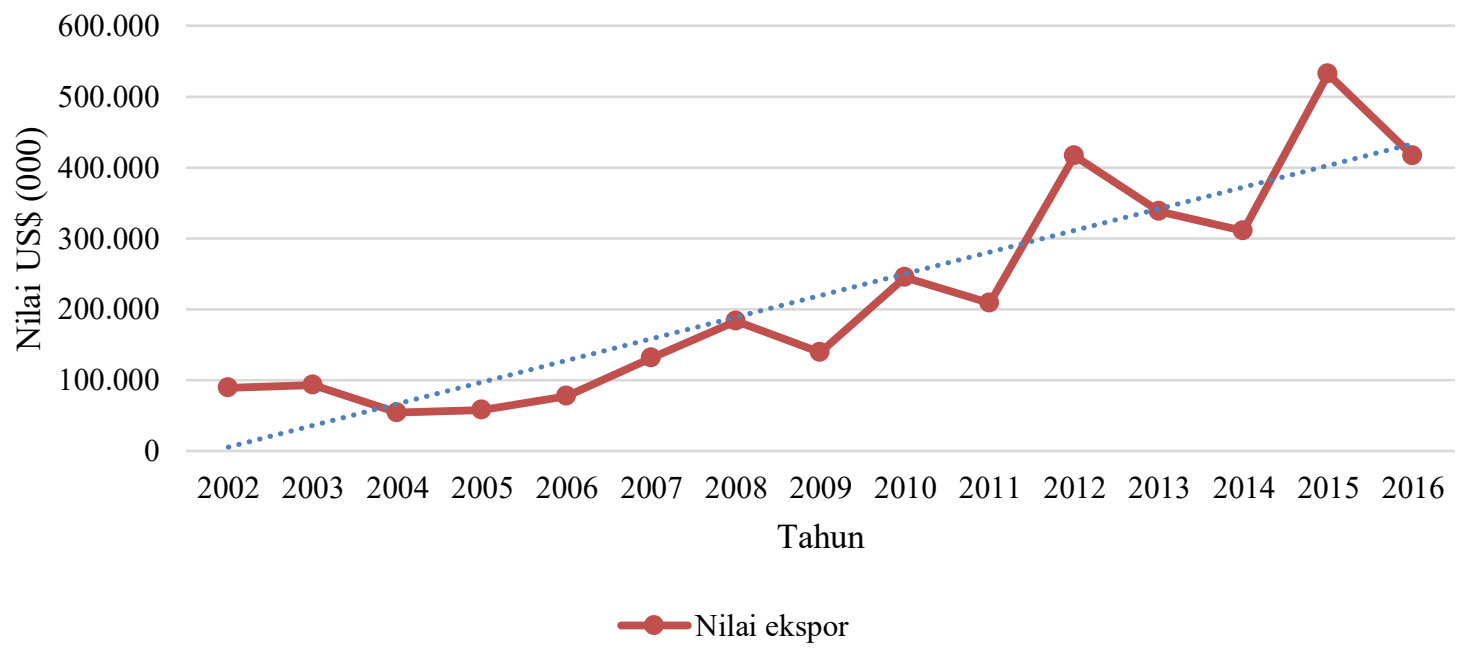

Sumber: ITC, 2017 (diolah)

Gambar 2. Perkembangan nilai ekspor lada Indonesia tahun 2002-2016 
Indonesia ke setiap negara tujuan pernah mengalami perubahan. Ada beberapa negara yang memperlihatkan volume impor lada dari Indonesia yang cenderung selalu meningkat, seperti Vietnam. Dimana tahun 2015 volume ekspor lada ke Vietnam meningkat sebesar $76.72 \%$, meningkat dibandingkan tahun 2011. Selain itu, ada juga beberapa negara yang memperlihatkan permintaan impor lada dari Indonesia yang memiliki kecenderungan berfluktuasi bahkan trennya cenderung menurun, seperti Amerika Serikat dimana pada tahun 2012 ekspor lada Indonesia mencapai 15.065 ton, namun menurun sebesar $76,49 \%$ menjadi 8.536 ton pada tahun 2016. Situasi ini memberikan gambaran bahwa ada beberapa negara tujuan ekspor lada Indonesia yang sudah jenuh terhadap lada Indonesia yang permintaannya semakin menurun dan ada juga beberapa negara tujuan ekspor yang permintaan terhadap lada Indonesia justru semakin meningkat.

Permintaan lada dunia diperkirakan akan terus mengalami peningkatan setiap tahun. Menurut ITC (2017), tingkat permintaan terhadap lada dunia diperkirakan akan terus mengalami peningkatan sebesar $1,4 \%$ setiap tahunnya. Pertumbuhan permintaan lada berpotensi terus meningkat seiring semakin bertambahnya jumlah penduduk dan semakin berkembangnya industri makanan dan kesehatan. Sebagian besar produksi lada nasional diperuntukan untuk memenuhi kebutuhan ekspor sebagai salah upaya pemenuhan kebutuhan lada dunia. Sedangkan sisanya sebaanyak $20 \%$ dipergunakan untuk memenuhi kebutukan konsumsi lokal (Fazaria, 2016).

Selain permintaan lada yang cenderung mengalami peningkatan, harga jual lada juga mengalami peningkatan setiap tahun di pasar internasional. Situasi ini memberikan gambaran bahwa lada merupakan komoditas perkebunan yang strategis. International Pepper Community (IPC) pada tahun 2017 merilis harga lada dunia yang terus mengalami peningkatan yang signifikan dalam kurun tiga tahun terakhir (2013-2015). Pada tahun 2015 harga lada hitam dunia tercatat pada US\$ 9.391 per ton, harga ini sangat jauh jika dibandingkan dengan harga pada tahun 2013 yang yang hanya US\$ 6.850 per ton. Demikian pula dengan harga lada putih yang pada tahun 2015 tercatat US\$ 13.678 dan melampaui harga lada putih pada tiga tahun sebelumnya yang berada pada US\$ 9.613 per ton. Menurut Herlina (2011), beberapa faktor yang memungkinkan terjadinya lonjakan harga lada dunia karena semakin menurunnya produksi lada di beberapa negara produsen lada dunia yang disebabkan oleh cuaca buruk, berkurangnya persediaan, dan meningkatnya permintaan lada dunia. Melonjaknya harga lada dunia memberikan dampak terhadap penawaran 
lada Indonesia ke pasar dunia yang meningkat. Seperti terlihat pada Gambar 2, pergerakan nilai ekspor lada selama 15 tahun terakhir memperlihatkan perkembangan yang fluktuatif yang disebabkan oleh perubahan harga dan volume ekspor lada dunia. Meskipun demikian, Gambar 2 juga memperlihatkan tren yang meningkat dengan cukup baik yang dibuktikan dengan laju pertumbuhan ekspor rata-rata sebesar $17,38 \%$ per tahun. Tahun 2015 merupakan tahun dengan pertumbuhan nilai ekspor lada tertinggi yang dicapai Indonesia dengan nilai US\$ 531.642.000, dengan pertumbuhan nilai ekspor mencapai 99,59\% dari tahun 2014. Kemungkinan terjadinya peningkatan ekspor tersebut karena harga jual lada di pasar dunia yang semakin meningkat. Kecenderungan peningkatan harga ini akan terus berlangsung yang diakibatkan permintaan lada dunia yang terus meningkat. Hal ini memberikan gambaran bahwa perdagangan lada Indonesia di pasar internasional di masa mendatang masih berpotensi untuk terus dikembangkan.

\section{SITUASI TERKINI}

Volume produksi lada Indonesia pada tahun 2011 sampai dengan tahun 2015 mengalami fluktuasi, namun jika melihat dari tren pergerakannya memperlihatkan kecenderungan meningkat dengan laju pertumbuhan rata-rata sebesar 11,92\% setiap tahunnya. Produksi lada tertinggi Indonesia dapat terlihat pada tahun 2015, yaitu 80.000 ton. Data ini juga memperlihatkan produksi lada pada tahun 2013 sebesar 63.000 ton atau mengalami penurunan sebesar 15\% dari tahun 2012, demikian pula pada tahun 2014 mengalami penurunan sebesar 18\%. Situasi yang sama juga terjadi dengan volume ekspor lada Indonesia, pergerakan volume ekspor lada Indonesia dari tahun 2011 hingga 2015 juga memperlihatkan perkembangan yang fluktuatif. Volume ekspor lada tertinggi Indonesia tercatat pernah tercapai pada tahun 2012 sebesar 62.608 ton, sehingga pada tahun tersebut merupakan pencapaian peningkatan volume ekspor lada tertinggi Indonesia, yaitu sebesar 72\%. Rata-rata proporsi volume ekspor lada Indonesia terhadap total produksinya mencapai 34\%. Situasi ini menunjukkan tingginya konsentrasi Indonesia untuk memasok produksi ladanya untuk pemenuhan kebutuhan lada dunia. Secara terinci perkembangan perkembangan produksi dan ekspor lada Indonesia tercantum pada Gambar 3.

Apabila dievaluasi, terdapat fenomena dimana tren ekspor lada Indonesia menunjukkan pertumbuhan yang kurang berkembang. Hal ini dapat terlihat bahwa meskipun tren pergerakan ekspor lada Indonesia menunjukkan peningkatan, 


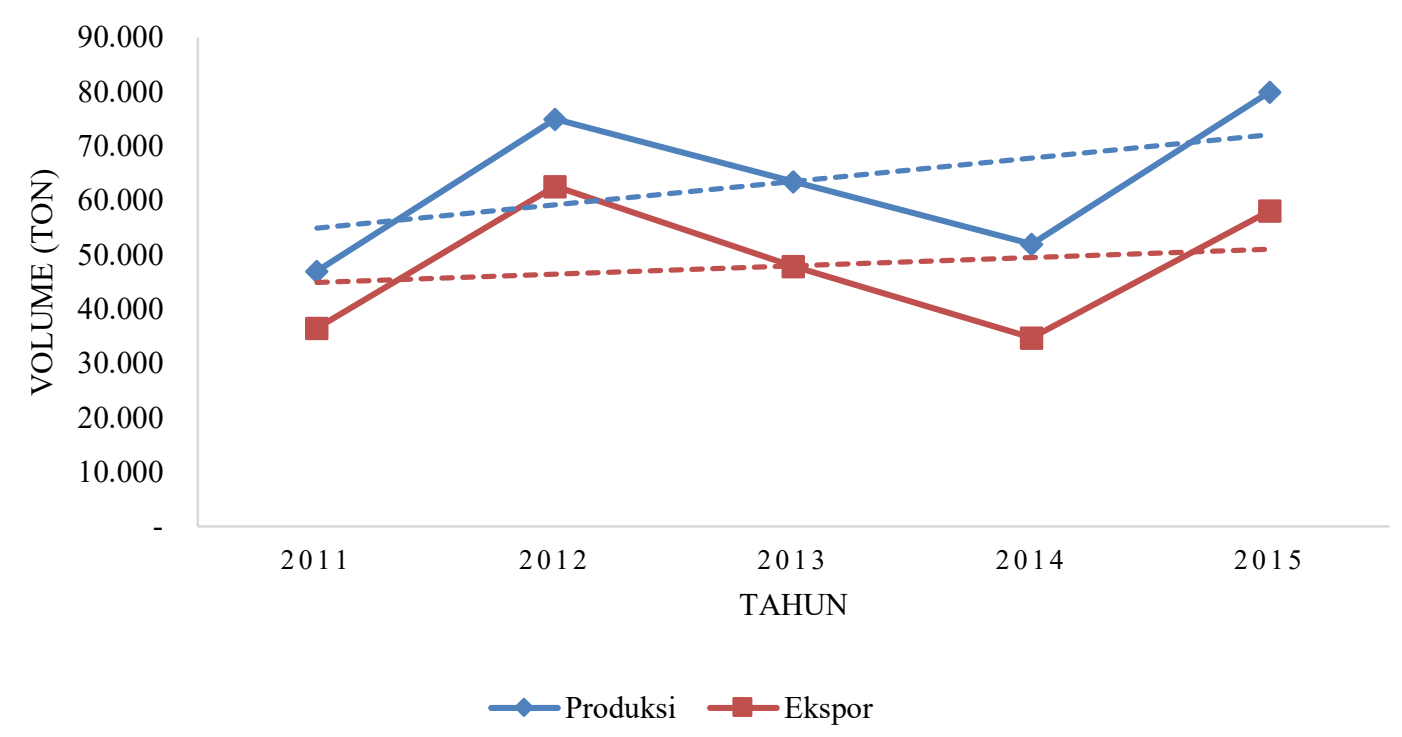

Sumber: IPC, 2017 (diolah)

Gambar 3. Perkembangan volume produksi dan ekspor lada Indonesia tahun 2011-2015

namun laju pertumbuhan rata-ratanya ternyata lebih rendah daripada laju pertumbuhan rata-rata volume produksinya, dimana laju pertumbuhan rata-rata volume ekspor sebesar 9,22\% per tahun. Seharusnya, laju pertumbuhan lada Indonesia yang cukup tinggi $(11,92 \%)$ serta tingkat konsumsi lada dalam negeri yang rendah bisa memberikan peluang untuk mendorong volume ekspor lada Indonesia semakin meningkat.

Situasi pertumbuhan ekspor yang kurang berkembang ini akan memengaruhi terhadap pangsa ekspor lada Indonesia di pasar internasional yang berfluktuasi pada setiap tahunnya sehingga menjadikan Indonesia sebagai negara eksportir lada terbesar kedua di dunia, meskipun dari sisi produksi seharusnya Indonesia berpotensi memperoleh hasil yang lebih baik. Ada berbagai faktor yang melatarbelakangi kurang berkembangnya ekspor lada
Indonesia, salah satunya adalah berupa daya saing lada Indonesia di pasar dunia. Daya saing yang lemah atau kuat terhadap suatu produk di pasar internasional akan memberikan pengaruh terhadap besar atau kecilnya volume ekspor komoditas tersebut.

Salah satu upaya untuk meningkatkan ekspor lada Indonesia adalah dengan meningkatkan kualitas dan daya saing terhadap komoditas ekspor tersebut, sehingga diharapkan kedepan ekspor lada Indonesia dapat mengimbangi atau bahkan mengalahkan negara pesaing. Selain itu, daya saing dan perdagangan lada Indonesia juga dipengaruhi oleh perilaku dan kinerja negara pesaing lainnya. Saat ini, selain berupaya meningkatkan kapasitas produksi lada dalam negerinya, beberapa negara produsen lada ini juga terlihat begitu gencarnya berupaya meningkatkan kualitas lada dengan memberikan nilai tambah terhadap produk lada, sehingga produk lada 
negara tersebut dapat diterima dengan baik oleh pasar bahkan bila perlu mengambil alih pangsa pasar negara eksportir lainnya. Situasi ini patut diwaspadai oleh Indonesia sebagai salah satu eksportir lada terbesar di dunia untuk terus berupaya mendorong kualitas lada nasional agar lebih berdaya saing di pasar internasional.

Selain mendorong peningkatan kualitas lada, negara lainnya seperti Vietnam juga memiliki kemampuan ekspor yang jauh lebih besar dari Indonesia selama 15 tahun terakhir, serta beberapa negara eksportir lainnya yang berpotensi untuk terus meningkatkan volume ekspornya, sehingga tentunya memiliki peluang untuk merebut pangsa ekspor lada Indonesia kedepan. Vietnam merupakan negara pesaing utama Indonesia dalam memperebutkan pangsa pasar lada dunia. Tentunya ini bisa menjadi ancaman serius karena pasar ekspor Indonesia dan Vietnam memilliki kecenderungan yang sama, yaitu dibeberapa negara maju seperti di Amerika Serikat, pasar Eropa, dan beberapa di negara Asia. Sama seperti Indonesia, Vietnam merupakan salah satu produsen lada terbesar di dunia, bahkan produksi lada Vietnam jauh lebih tinggi dari Indonesia.

Selain berkonsentrasi terhadap persaingan dengan negara pesaing, perdagangan lada Indonesia di pasar dunia juga dipengaruhi oleh beberapa faktor lainnya. Untuk dapat meningkatkan volume ekspor lada Indonesia di pasar dunia, beberapa faktor yang diduga perlu diperhatikan adalah adanya negara tujuan ekspor lada Indonesia yang memiliki karakteristik dan lokasi yang berbeda-beda, seperti Gross Domestic Product (GDP) dan jarak antar negara (Meiri, 2013). Beberapa faktor yang membedakan perdagangan lada Indonesia ke negara tujuan ekspor dapat menjadi faktor penentu dalam aliran perdagangan lada Indonesia ke beberapa negara tujuan ekspor utama. Selain itu, perlu juga menjadikan nilai RCA sebagi faktor penting dalam memengaruhi aliran perdagangan lada yaitu dengan berupaya meningkatkan produktivitas lada nasional yang masih rendah. Analisis terhadap aliran perdagangan lada ini setidaknya dapat memberikan gambaran tentang faktorfaktor apa sajakah yang memengaruhi perdagangan lada Indonesia di pasar internasional. Penelitian ini diharapkan dapat memberikan strategi yang tepat untuk meningkatkan daya saing lada Indonesia melalui berbagai rekomendasi kebijakan.

\section{METODOLOGI}

Secara keseluruhan data yang dipergunakan dalam penelitian ini merupakan data sekunder yang menjadi database dari beberapa lembaga atau instansi berupa data panel yang merupakan penggabungan dari data time series dan cross section. Data cross section terdiri dari 10 negara 
tujuan ekspor utama lada Indonesia seperti Vietnam, Amerika serikat, India, Singapura, Jerman, Perancis, Belanda, Taiwan, Malaysia dan China. Sementara data time series yang dipergunakan adalah selama 15 tahun, yaitu dari tahun 2002 sampai tahun 2016. Data diperoleh dari International Pepper Community (IPC), United Nations Commodity and Trade (UN Comtrade), United States Department of Agriculture (USDA), World Trade Organization (WTO), serta data lainnya dari internet dan literatur ilmiah. Metode analisis yang digunakan adalah Analisis Data Panel dengan Gravity Model dan Analisis Potensi Perdagangan.

\section{ANALISIS DAN SOLUSI}

\section{Faktor yang Memengaruhi Aliran Perdagangan Lada Indonesia di Pasar Internasional}

Model estimasi yang terbaik dalam penelitian ini adalah fixed effect model. Model estimasi ini didapat dari hasil chow test dan hausman test. Chow test digunakan untuk memilih model antara common effect model dan fixed effect model. Hasil dari chow test ini pada model adalah nilai probability $0.000<0.05$. Kedua model tersebut tolak Ho artinya model yang lebih sesuai adalah menggunakan fixed effect model. Selanjutnya diuji lagi menggunakan hausman test untuk memilih diantara fixed effect model dengan random effect model. Hasil dari hausman test model yang estimasi menunjukan nilai probability $0.047<0.05$. Kedua model tersebut tolak $\mathrm{H}_{0}$, artinya model yang lebih sesuai adalah menggunakan fixed effect model. Dari hasil uji tersebut diputuskan model yang akan diestimasi lebih lanjut menggunakan fixed effect model.

Secara keseluruhan, hasil dari analisis gravity model pada Tabel 8 memperlihatkan nilai probability (F-statistic) sebagai uji kelayakan model adalah 0.000. Dari hasil (Fstatistic) ini dapat menerangkan bahwasanya minimal terdapat satu variabel independent yang memengaruhi variabel dependent. Kecocokan model dapat dilihat dari koefisien determinasi $\left(\mathrm{R}^{2}\right)$ yang dimiliki model tersebut. Koefisien determinasi $\left(\mathrm{R}^{2}\right)$ dari model tersebut adalah 0,95 atau 95\%. Koefisien determinasi pada model ini artinya sebesar 95\% variabel-variabel independent pada model pertama mampu menjelaskan variabel independent dan 5 persen mampu dijelaskan oleh variabel independent yang tidak termasuk di dalam model. Keenam variabel independen yang diteliti pada penelitian ini, seperti GDP riil perkapita Indonesia, GDP riil perkapita negara tujuan, jarak ekonomi Indonesia dengan negara tujuan, nilai tukar, dan RCA memiliki pengaruh yang sangat signifikan, namun tidak demikian dengan dummy penerapan tarif impor di negara tujuan yang justru memiliki pengaruh tidak signifikan. Sementara hanya variabel GDP riil per kapita negara tujuan ekspor dan RCA Indonesia yang memiliki tanda hubungan 
yang sesuai dengan hipotesis di awal. Secara terinci, hasil pendugaan dari model dijelaskan di bawah ini.

\section{GDP Riil per Kapita Indonesia}

GDP riil perkapita Inodonesia menggambarkan perkembangan perekonomian dari negara eksportir lada dalam penelitian ini adalah Indonesia. Pertumbuhan ekonomi dapat dilihat dari neraca perdagangan dengan melihat volume ekspor lada Indonesia pertahun. Semakin tinggi volume ekspor lada dapat berpengaruh positif terhadap pertumbuhan GDP negara eksportir dan sebalikya (ceteris paribus). GDP eksportir yang semakin tinggi dapat memberikan dampak postif terhadap perekonomian dalam negeri yang semakin membaik, sehingga konsumsi produk dan jasa masyarakat juga akan semakin meningkat. Adanya peningkatan konsumsi masyarakat langsung maupun industri pengolahan di dalam negeri akan berdampak terhadap penurunan ekspor lada Indonesia. Namun demikian, hasil ini dimungkinkan bisa berbeda terhadap produk non primer, misalnya pada komoditas lada.

Berdasarkan pada Tabel 1, hipotesa penelitian bisa dibuktikan melalui hasil estimasi yang diperoleh pada data tersebut yang menunjukkan bahwa variabel GDP riil per kapita memiliki pengaruh yang signifikan pada taraf nyata 5\% terhadap volume ekspor lada Indonesia. Data tersebut dapat terlihat pada nilai probabilitas variabel GDP riil perkapita Indonesia yang lebih kecil dari taraf nyatanya $(0.00<0.05)$. Koefisien GDP eksportir dari model ini adalah sebesar 0,522. Koefisien tersebut memiliki tanda negatif dan tidak sesuai dengan hipotesis penelitian.

Tabel 1 Hasil pendugaan aliran perdagangan lada Indonesia terhadap negara-negara tujuan ekspor

\begin{tabular}{lrr}
\hline \multicolumn{1}{c}{ Variabel } & Koefisien & \multicolumn{1}{c}{ Prob. } \\
\hline C & -32.30369 & 0.0000 \\
GDP riil perkapita Indonesia & -0.522272 & 0.0067 \\
GDP riil perkapita negara tujuan ekspor & 4.717436 & 0.0000 \\
Jarak ekonomi Indonesia dengan negara tujuan ekspor & 0.124855 & 0.0001 \\
Nilai tukar rupiah terhadap mata uang negara tujuan ekspor & -0.669879 & 0.0000 \\
Dummy penerapan tarif impor negara tujuan ekspor & 0.125452 & 0.4908 \\
RCA Indonesia & 0.747044 & 0.0000 \\
R-squared & & 0.958136 \\
Adjusted R-squared & & 0.953449 \\
S.E. of regression & & 1.044626 \\
F-statistic & & 204.4545 \\
Prob(F-statistic) & & 0.000000 \\
\hline
\end{tabular}


Hasil estimasi tersebut memberikan pengertian bahwa setiap adanya peningkatan GDP riil perkapita Indonesia sebesar 1\% akan berdampak terhadap semakin menurunnya volume perdagangan lada Indonesia sebesar -0,522 ton di pasar internasional, dan sebaliknya (ceteris paribus).

Kondisi ini sesuai dengan teori yang dikemukakan oleh Mankiw (2004) yang menyatakan bahwa GDP nasional merupakan penjumlahan dari konsumsi, investasi, pengeluaran pemerintah dan ekspor-impor. Maka dari itu, semakin meningkatnya GDP riil perkapita suatu negara mencerminkan semakin membaiknya daya beli masyarakat pada negara eksportir sehingga memiliki dampak terhadap semakin meningkatnya konsumsi lada dalam negeri. Menurut data International Pepper Community (2017) tentang perkembangan konsumsi lada nasional, baik sebagai konsumsi langsung di masyarakat maupun untuk industri pengolahan lada, seperti pengolahan makanan, kesehatan dan kosmetik, maka pada tahun 2008 hingga tahun 2017 memperlihatkan perkembangan permintaan lada yang cenderung semakin meningkat dengan pertumbuhan rata-rata sebesar $7.64 \%$ per tahun. Hal ini memberikan dugaan bahwa semakin meningkatnya GDP rill per kapita Indonesia akan memberikan dampak terhadap semakin meningkatnya permintaan konsumsi lada dalam negeri sehingga menyebabkan volume ekspor lada Indonesia ke pasar internasional mengalami penurunan. Perkembangan GDP riil perkapita suatu negara yang semakin meningkat setiap tahunnya bisa mencerminkan kondisi daya beli masyarakat yang juga semakin meningkat, sehingga akan berdampak terhadap konsumsi produk tersebut juga mengalami peningkatan. Hasil penelitian ini memiliki kesamaan dengan penelitian Kareem (2016) dan Khaliqi (2017).

\section{GDP Rill per Kapita Negara Tujuan Ekspor}

GDP riil perkapita terhadap negara tujuan ekspor atau importir memiliki maksud yang sama dengan dengan GDP rill perkapita pada negara eksportir(Indonesia), yakni merupakan indikator kemampuan daya beli masyarakat terhadap produk di suatu negara. Hasil penelitian pada Tabel 2 menunjukan bahwa GDP riil perkapita negara tujuan ekspor (negara importir lada) memiliki pengaruh positif yang signifikan pada taraf nyata 5\% terhadap volume ekspor lada Indonesia.

Hasil estimasi tersebut terjadi karena nilai probabilitas variabel GDP rill perkapita negara tujuan ekspor adalah sebesar 4,717 dengan tanda koefisien positif dan sesuai dengan dengan hipotesis. Hasil tersebut memberikan estimasi bahwa setiap terjadinya peningkatan GDP riil perkapita negara tujuan ekspor sebesar 1\% dapat 
menyebabkan semakin meningkatnya volume perdagangan lada Indonesia di pasar internasional sebesar 4,717 ton.

GDP riil perkapita negara tujuan ekspor merupakan indikator dari kemakmuran suatu negara. Semakin membaik atau meningkatnya GDP riil negara importir akan berdampak terhadap semakin tingginya kemampuan daya beli penduduk tersebut dalam mengkonsumsi suatu produk. Maka hasil penelitian ini dapat mengindikasikan bahwa GDP riil perkapita negara tujuan ekspor (importir) akan memberikan pengaruh positif yang signifikan terhadap potensi semakin meningkatnya aliran perdagangan lada Indonesia di pasar internasional. Hasil penelitian ini memiliki kesamaan dengan penelitian Bassiony (2012).

\section{Jarak Ekonomi Indonesia dengan Negara Tujuan Ekspor}

Jarak ekonomi Indonesia dengan negara tujuan ekspor memberikan arti tentang biaya transportasi yang dikeluarkan dalam melakukan perdagangan. Perubahan jarak dalam perdagangaan bilateral antar negara dapat mempengaruhi terhadap harga suatu produk. Hasil penelitian ini menunjukan fenomena bahwa jarak ekonomi Indonesia dengan negara tujuan ekspor lada Indonesia berpengaruh signifikan sebesar 5\%, sehingga setiap terjadi penguatan atan pelemahan mata uang rupiah maka akan mempengaruhi terhadap volume perdagangan lada Indonesia di pasar internasional. Koefisien variabel jarak ekonomi pada model estimasi menunjukan pengaruh positif sebesar 0,124. Koefisien variabel ini memberikan petunjuk bahwa peningkatan jarak ekonomi sebesar 1\% dapat meningkatkan volume ekspor lada Indonesia di pasar internasional sebesar 0,124 ton.

Hasil estimasi ini tentunya tidak sesuai dengan hipotesa di awal penelitian karena memiliki tanda koefisien yang berbeda. Namun temuan ini bisa memberikan fenomena bahwa ternyata jarak ekonomi tidak selalu memberikan pengaruh negatif terhadap pertumbuhan volume ekspor perdagangan Indonesia ke negara mitra dagang. Hasil penelitian ini bisa memberikan bukti bahwasanya pusat perdagangan lada Indonesia lebih tertuju kepada negara-negara yang memiliki kedekatan wilayah dengan Indonesia, terutama dikawasan Asia Tenggara. Berdasarkan informasi yang tercatat di ITC (2017), pada periode dua tahun terakhir, hampir 40\% lada Indonesia di ekspor ke negara Vietnam. Selain itu, lada merupakan komoditas yang memiliki keunikan untuk bisa tumbuh dan berkembang dengan baik di kawasan tropis. Sehingga tidak semua negara tujuan ekspor, khususnya di kawasan Eropa dan beberapa negara di Amerika, memiliki kemampuan untuk memproduksi lada. Oleh karena itu, meskipun jarak 
ekonomi memiliki kecenderungan meningkat di pasar dunia, beberapa negara importir akan tetap melakukan perdagangan dengan Indonesia guna memenuhi kebutuhan konsumsi lada di negara importir tersebut.

\section{Nilai Tukar Rupiah terhadap Mata Uang Negara Tujuan Ekspor}

Nilai mata uang dunia yang mengalami apresiasi menyebabkan daya beli terhadap mata uang tersebut akan mengalami peningkatan di pasar internasional atau sebaliknya apabila suatu negara mengalami depresiasi terhadap mata uang negara tersebut maka volume ekspor akan meningkat dari tahun sebelumnya (Mankiw, 2014). Pada Hasil penelitian menunjukkan bahwa kondisi nilai tukar rupiah terhadap terhadap volume ekspor lada Indonesia memiliki pengaruh yang signifikan pada taraf nyata 5\%. Sehingga saat terjadinya apresiasi dan depresiasi rupiah terhadap mata uang negara tujuan ekspor maka akan berdampak terhadap perubahan nilai ekspor lada Indonesia dari negara-negara importir. Hasil estimasi variabel tersebut tidak sesuai dengan hipotesis yang dibentuk di awal penelitian.

$$
\text { Hasil estimasi gravity model }
$$
menunjukkan fakta bahwa variabel nilai tukar mempunyai nilai sebesar $-0,669$ dan memiliki pengaruh yang negatif terhadap volume ekspor lada Indonesia. Interpretasi dari koefisien nilai tukar rupiah tersebut adalah dengan adanya peningkatan nilai tukar rupiah Indonesia sebesar 1\% maka akan menurunkan ekspor lada Indonesia sebesar -0,669 ton. Nilai tukar rupiah yang terapresiasi akan meningkatkan posisi rupiah terhadap mata uang asing maka negara importir harus membayar lebih besar dari nilai seperti biasanya. Selain itu, penguatan rupiah juga memberikan pengertian terhadap kondisi perekonomian Indonesia yang semakin meningkat dan semakin melemahnya perekonomian negara-negara importir. Hasil ini tentunya akan memberikan dugaan bahwa dampak dari perekonomian Indonesia yang semakin meningkat dan melemahnya perekonomian negara importir secara otomatis masyarakat akan menurunkan konsumsi baik dalam negeri maupun produk impor. Hasil penelitian ini memiliki kesaman dengan penelitian Rahmah (2016).

\section{Penerapan Tarif Impor Negara Tujuan Ekspor}

Hasil estimasi dari pemberlakuan terhadap tarif impor lada Indonesia dari negara tujuan ekspor memiliki pengaruh yang tidak signifikan pada taraf nyata 5\% terhadap volume ekspor lada Indonesia. Hal ini dapat dilihat dari nilai probabilitas variabel tarif impor yang lebih besar dari taraf nyatanya, yatu $0.00<0,490$. Koefisien variabel tarif impor tidak memiliki pengaruh terhadap volume perdagangan lada Indonesia yang memiliki nilai sebesar 0.125. 
Hasil estimasi ini memberikan gambaran bahwa semakin meningkatnya tarif impor lada maka tidak akan berdampak terhadap semakin menaik atau menurunnya volume perdagangan lada Indonesia di pasar internasional. Sementara hipotesis variabel tarif impor memiliki pengaruh yang yang negatif.

Sebagaimana yang telah dijelaskan sebelumnya, penerapan kebijakan sangat dipengaruhi oleh niat dari pemerintah negara importir untuk menerapkan kebijakan tersebut. Sementara itu, kebijakan tarif impor merupakan salah satu dari bentuk hambatan perdagangan internasional yang dimungkinkan untuk menaikkan posisi tawar perdagangan negara importir melalui negosiasi. Kebijakan ini merupakan bentuk perlindungan yang diterapkan oleh negara importir guna melindungi produsen lokal. Namun kebijakan tarif impor dapat memberikan dampak positif bagi Indonesia, pemerintah Indonesia berupaya secara langsung untuk meningkatkan kualitas produk sehingga mampu meningkatkan daya saing dan bisa mengembangan pasar yang lebih luas lagi. Selain itu tarif impor juga merupakan bentuk kekhawatiran negara importir untuk mengurangi impor dan meningkakan volume ekspor negara mereka. Artinya, bagi sebagian negara maju, kebijakan mengurangi impor adalah untuk meningkatkan insentif ekspor mereka guna menyeimbangkan neraca perdagangan agar surplus (Tokarick, 2007).

Oleh karena itu, hasil penelitian ini menunjukkan bahwa kebijakan tarif impor dari negara importir tidak memberikan pengaruh terhadap aliran perdagangan lada Indonesia karena hampir sebagian besar permintaan impor Indonesia dilakukan oleh negara-negara yang memiliki hubungan perdagangan secara bilateral dengan Indonesia sehingga penerapan kebijakan tarif impor dapat dihindari.

\section{RCA Negara Indonesia terhadap Negara Tujuan Ekspor}

Hasil estimasi yang diperoleh menunjukan bahwa variabel RCA memiliki pengaruh yang sangat signifikan karena nilai probabilitas lebih kecil dari taraf nyata 5\%. Dengan demikian, hasil tersebut menunjukkan bahwa perubahan pada variabel RCA dapat mempengaruhi volume perdagangan lada Indonesia di pasar internasional. Berdasarkan hasil estimasi, variabel RCA memiliki tanda koefisien yang sesuai dengan hipotesis, yaitu menunjukan hubungan yang positif. Hal ini memberikan gambaran bahwa perubahan terhadap nilai RCA sebesar $1 \%$ menyebabkan volume perdagangan lada mengalami peningkatan sebesar 0,747 ton. Hal ini selaras dengan dengan teori Porter (1990) yang mengungkapkan bahwa keunggulan daya saing menyebabkan kemampuan suatu negara untuk menghasilkan suatu 
komoditas menjadi lebih efisien, sehingga diharapkan dapat memenangkan persaingan dengan negara pesaing.

\section{Potensi Perdagangan Lada Indonesia di Negara Tujuan Ekspor}

Permintaan lada dunia yang terus meningkat membuat peluang Indonesia semakin besar untuk meningkatkan volume ekspor lada nasional di pasar internasional. Salah satu strategi untuk bisa memanfaatkan
Penelitian ini potensi perdagangan ini menggunakan hasil estimasi koefisien dari persamaan gravity model dalam melakukan prediksi volume perdagangan terhadap perdagangan aktual suatu negara. Berdasarkan hasil analisis rasio potensi perdagangan lada Indonesia dapat diketahui bahwa perdagangan lada Indonesia di sepuluh negara tujuan ekspor selama 15 tahun terakhir memiliki kecenderungan

Tabel 2. Rasio potensi perdagangan lada Indonesia

\begin{tabular}{|c|c|c|c|c|c|c|c|c|c|c|}
\hline \multirow{2}{*}{ Tahun } & \multicolumn{10}{|c|}{ Negara } \\
\hline & VNM & USA & IND & SIN & JER & PRC & BLD & TWN & MAL & CIN \\
\hline 2003 & 0.02 & 0.36 & 0.42 & 0.73 & 1.20 & 1.80 & 1.61 & 2.94 & 3.41 & 0.00 \\
\hline 2004 & 0.04 & 0.39 & 0.45 & 0.79 & 1.21 & 2.32 & 1.78 & 2.72 & 4.48 & 5.71 \\
\hline 2005 & 0.07 & 0.40 & 0.48 & 0.80 & 1.26 & 2.42 & 1.74 & 2.47 & 3.77 & 6.39 \\
\hline 2006 & 0.08 & 0.41 & 0.48 & 0.83 & 1.23 & 1.92 & 1.81 & 2.40 & 2.72 & 3.58 \\
\hline 2007 & 0.10 & 0.42 & 0.50 & 0.90 & 1.22 & 2.07 & 1.70 & 2.36 & 2.55 & 4.24 \\
\hline 2008 & 0.11 & 0.41 & 0.49 & 0.93 & 1.25 & 1.68 & 1.73 & 2.61 & 2.72 & 4.30 \\
\hline 2009 & 0.12 & 0.42 & 0.49 & 1.00 & 1.28 & 1.88 & 1.83 & 2.29 & 2.59 & 0.00 \\
\hline 2010 & 0.13 & 0.44 & 0.54 & 0.96 & 1.29 & 1.76 & 1.77 & 2.65 & 2.29 & 2.83 \\
\hline 2011 & 0.16 & 0.47 & 0.57 & 1.00 & 1.41 & 1.86 & 1.94 & 2.70 & 2.45 & 2.65 \\
\hline 2012 & 0.16 & 0.47 & 0.56 & 1.04 & 1.33 & 1.91 & 1.89 & 2.54 & 2.49 & 2.50 \\
\hline 2013 & 0.17 & 0.50 & 0.62 & 0.98 & 1.35 & 1.77 & 1.82 & 2.66 & 2.61 & 2.79 \\
\hline 2014 & 0.20 & 0.56 & 0.62 & 0.96 & 1.34 & 1.87 & 2.04 & 2.39 & 2.66 & 2.72 \\
\hline 2015 & 0.19 & 0.55 & 0.63 & 1.00 & 1.34 & 1.83 & 1.96 & 2.53 & 2.62 & 2.48 \\
\hline 2016 & 0.21 & 0.57 & 0.62 & 1.10 & 1.39 & 1.65 & 1.87 & 2.38 & 2.57 & 2.65 \\
\hline Rata-rata & 0.12 & 0.42 & 0.50 & 0.87 & 1.21 & 1.78 & 1.70 & 2.38 & 2.66 & 3.57 \\
\hline \multicolumn{11}{|c|}{ Keterangan: } \\
\hline VNM: Viet & & & : India & & : Jerr & & $D:$ Be & & AL : N & \\
\hline USA : Ame & a Serikat & & : Singa & & : Per & & $\mathrm{N}: \mathrm{Ta}$ & & $\mathrm{N}: \mathrm{Ch}$ & \\
\hline
\end{tabular}

peluang tersebut adalah dengan mengetahui potensi perdagangan lada Indonesia pada masing-masing negara tujuan ekspor dengan tujuan untuk mengetahui posisi perdagangan Indonesia masuk dalam kategori under trade atau sudah over trade. Secara terinci hasil perhitungan rasio perdagangan lada Indonesia dapat dilihat pada Tabel 2. fluktuasi. Beberapa negara yang memiliki nilai rata-rata potensi perdagangan di atas satu adalah China, Malaysia, Taiwan, Belanda, Perancis, Jerman Singapura dan India. Hal ini memperlihatkan fakta bahwa kondisi perdagangan lada Indonesia di delapan negara tersebut berada dalam kondisi yang menguntungkan karena mengalami under trade, artinya kedelapan 
negara tujuan ekspor tersebut masih memiliki potensi perdagangan yang belum jenuh dan memberikan kesempatan bagi perdagangan lada Indonesia untuk terus meningkatkan volume ekspor di masa mendatang. Sementara Vietnam dan Amerika Serikat potensi pasarnya sudah mengalami over trade atau kejenuhan pasar karena nilai rasio potensi perdagangaan di kedua negara tersebut berada di bawah satu.

Vietnam dan Amerika Serikat merupakan pasar utama lada Indonesia selama kurun waktu tahun 2002 hingga tahun 2008. Hal ini dapat terlihat dari volume permintaan impor kedua negara yang selalu tertinggi dibendingkan dengan negara tujuan ekspor lainnya. Bahkan volume impor lada Vietnam di tahun 2015 dan tahun 2016 sempat menggeser posisi Amerika serikat sebagai tujuan utama ekspor lada Indonesia (ITC, 2017). Meskipun demikian, ternyata hal ini bertolak belakang dengan rasio potensi perdagangan yang sangat kecil sehingga menempatkan kedua negara berada pada posisi terakhir. Hal ini membuktikan bahwa volume ekspor yang tertinggi tidak selalu berkorelasi terhadap potensi perdagangan yang tertinggi juga.

Selain itu, potensi perdagangan Vietnam sebenarnya berada pada posisi over trade meskipun memiliki permintaan impor lada tertinggi. Kondisi ini berkaitan dengan kualitas lada ekspor domestik Vietnam yang menurun akibat kelebihan residu pestisida sehingga mendapat penolakan dari beberapa negara importir lada dunia (CBI, 2019). Dengan demikian, strategi pemerintah Vietnam dalam mempertahankan kuantitas ekspor, yaitu mencampur lada domestik dengan lada impor, kemudian melakukan reekspor kembali ke pasar lada dunia. Strategi ini cukup berhasil dan terbukti dengan permintaan impor lada Vietnam terhadap lada Indonesia yang senantiasa tertinggi sejak tahun 2015 hingga sekarang. Sebaliknya dengan Amerika serikat, permintaan impor lada negara tersebut menunjukkan tren yang menurun dan didukung dengan hasil rasio potensi perdagangan yang berada pada over trade. Amerika Serikat merupakan negara tujuan utama ekspor lada dari para produsen lada dunia. Hal ini terbukti dengan jumlah permintaan impor lada Amerika selalu berada posisi tertinggi (ITC, 2017). Semakin menurunnya permintaan impor lada Amerika Serikat terhadap lada Indonesia dapat mencerminkan bahwa persaingan ekspor lada di negara tersebut sangat ketat, selain juga karena jarak ekonomi yang jauh dari Indonesia sehingga memungkinkan beberapa wilayah yang memiliki kedekatan dengan Amerika Serikat mampu memanfatkan potensi tersebut.

Sementara China merupakan negara yang memiliki nilai rasio potensi 
perdagangan tertinggi di antara kesepuluh negara tujuan ekspor lada Indonesia, yaitu sebesar 3,57. Artinya, potensi perdagangan lada Indonesia di China memiliki peluang yang sangat baik untuk terus ditingkatkan. Total permintaan impor lada China dari pasar dunia secara keseluruhan mencapai 4 021 ton. Sementara Indonesia baru dapat memenuhi kebutuhan permintaan impor lada China sebesar $22.30 \%$. Permintaan lada tersebut memungkinkan untuk terus meningkat karena China merupakan negara yang memiliki populasi penduduk tertinggi di dunia dengan ditunjang pertumbuhan ekonomi yang terus meningkat pesat. Hubungan kedua negara yang cukup baik tentunya memberikan peluang bagi Indonesia untuk terus meningkatkan volume ekspor lada Indonesia ke China. Kondisi ini pernah terjadi pada tahun 2003 dan 2004 dimana nilai potensi perdagangan Indonesia mencapai nilai tertinggi hingga di atas 50 persen dari total permintaan impor lada China. Kondisi ini memberikan peluang besar bagi Indonesia untuk memperluas pangsa ekspor lada ke China. Selain itu, perdagangan lada di China yang cenderung fluktuatif terhadap setiap negara eksportir memberikan dugaan bahwa China merupakan negara yang masih memungkinkan untuk melakukan perjanjian perdagangan secara permanen dengan Indonesia. Kecenderungan ini terjadi karena pasar China yang sangat besar menyebabkan posisi permintaan perdagangan lada oleh China sangat tinggi.

\section{REFERENSI}

International Trade Center [ITC]. 2017. Trade Map Trade Statistic For International Business Development. Retrieved from https://trademap.org.

Kementerian Pertanian. 2015. Outlook Lada : Komoditas Pertanian Subsektor Perkebunan. Pusat Data dan Sistem Informasi Pertanian, Sekretariat Jenderal, Kementerian Pertanian. Jakarta.

Arifin, B. 2013. On the competitiveness and sustainability of the Indonesian agricultural export commodities. ASEAN Journal of Economics, Management and Accounting, 1(1), 81-100.

Balassa, B. 1965. Trade lberalization and revealed comparative advantage. The Manchaster School of Economic and Sosial Studies, 33, 92-123.

Baroh, I., Hanani, N., Setiawan, B., Koestiono, D. 2014. Indonesian coffee competitiveness in the International Market: Armington Model Application. American Journal of Economics, 4(4), 184194.

Boansi, D., Crentsil, C. 2013. Competitiveness and Determinants of Coffee Exports, Producer Price and Production for Ethiopia. Journal of Advanced Research in Economics and International Business, 1(1), 31-56.

Edwards, L., Schoer, V. 2002. Measures of competitiveness: a dynamic approach to South Africa's trade performance in the 1990s. South African Journal of Economics, 70(6), 1008-1046. 
Erkan, B., Yildirimci, E. 2015. Economic Complexity and Export Competitiveness: The Case of Turkey. Procedia-Social and Behavioral Sciences, 195, 524-533.

Gebre, Y. 2015. Determinants of Coffee Export Performance in Ethiopia. Journal of Economics and Sustainable Development, 6(5), 147-157.

Hamdy, H. 2001. Ekonomi Internasional Teori dan Kebijakan Perdagangan Internasional. Jakarta: Ghalia.

Hinloopen, J., Onderstal, S. 2010. Collusion and the choice of auction: An experimental study.

Krugman, P.R., Obstfeld, M. 2005. Ekonomi Internasional Teori dan Kebijakan 5th ed. Jakarta: PT. Indeks Kelompok Gramedia.

Meiri, A., Nurmalina, R., Rifin, A. 2013. Trade Analysis of Indonesian Coffee in International Market. Buletin RISTRI, 4(1), 3946.

Nhien, N.T.H. 2016. The Competitiveness of Vietnamese Coffee Into The EU
Market. Centria University of Applied Scinces Finlandia.

Özçelik, S.E., Erlat, G. 2013. Turkey's comparative advantages and dynamic market positioning in the EU market an analysis by extensive and intensive margins. Topics in Middle E astern and African Economies. 15(2):186-211

Rosiana, N., Nurmalina, R., Winandi, R., Rifin, A. 2017. The Level of Comparative Advantages of World Main Coffee Producers. Buletin Ilmiah Litbang Perdagangan, 11(2), 227-246.

Salvatore, D. 1997. Ekonomi Internasional (Terjemahan). Jakarta (ID): Erlangga.

Tambunan, T. 2001. Perekonomian Indonesia: Teori, Temuan dan Empiris. Jakarta: Ghalia.Özçelik SE. Erlat G, 2013. Turkey's comparative advantages and dynamic market positioning in the EU market an analysis by extensive and intensive margins. Topics in Middle $\mathrm{E}$ astern and African Economies. 15(2):186-211. 